\title{
ON THE CONTINUED INVOLVEMENT OF THE STATE IN THE SOCIO-ECONOMIC VIABILITY OF THE POST-SOVIET KOLYMA, RUSSIAN FAR NORTH
}

\author{
Elena Khlinovskaya Rockhill, \\ Lena Sidorova
}

Nothing happens until something moves. Albert Einstein

\begin{abstract}
In the $20^{\text {th }}$ and $21^{\text {st }}$ centuries the northern development project of the Russian Northeast was, and still is, a state bounded high modernist project. Clear aims of northern development and targeted use of certain tools, such as designing programmes to increase, or more recently, to reduce the population by relocating a 'surplus' population point at the social engineering character of these initiatives, then and now. Yet neither the Russian government nor the World Bank, both assisting northern residents to move out of the North, fully achieved their goal: people who were meant to relocate resisted such plans and stayed in the region using survival strategies that helped them to take advantage of the state's assistance to meet their own goals. The central argument of this paper is that life goes on, including the life of the state, that changes and develops too, despite the drastic outward appearance of the state's withdrawal and population out-migration.
\end{abstract}

Keywords: migration, state, Russian Arctic, grey economy, sustainable development, social engineering projects

\section{Part 1}

\section{Introduction}

This paper ${ }^{1}$ is concerned with the state-induced social development of the Magadan Region, or in geographic and local terms, Kolyma, one of Russia's Far Northern territories in the Russian Far East. The Region, which borders Chukotka, the Sakha Republic and Khabarovsk Krai, and comprises a territory of $462,464 \mathrm{~km}^{2}$, has a regional population of just over 144 thousand persons; 95,6 thousand of them live in the city of Magadan (Rosstat 2018. Photo 1).

The region is populated by predominantly non-Native people; the majority are Russian (81,4\%), followed by Ukranians $(6,2 \%)$ and other nationalities $^{2}$. The Magadan Region is located eight times zones from Moscow and can be reached only by airplane ${ }^{3}$. Since the 1930s, the region 
was so isolated that local inhabitants referred to other places as the materik, or mainland, feeling themselves to be living on a distant island. Before the 1920 s there was no coherent policy of colonisation that would facilitate the economic development of this region.

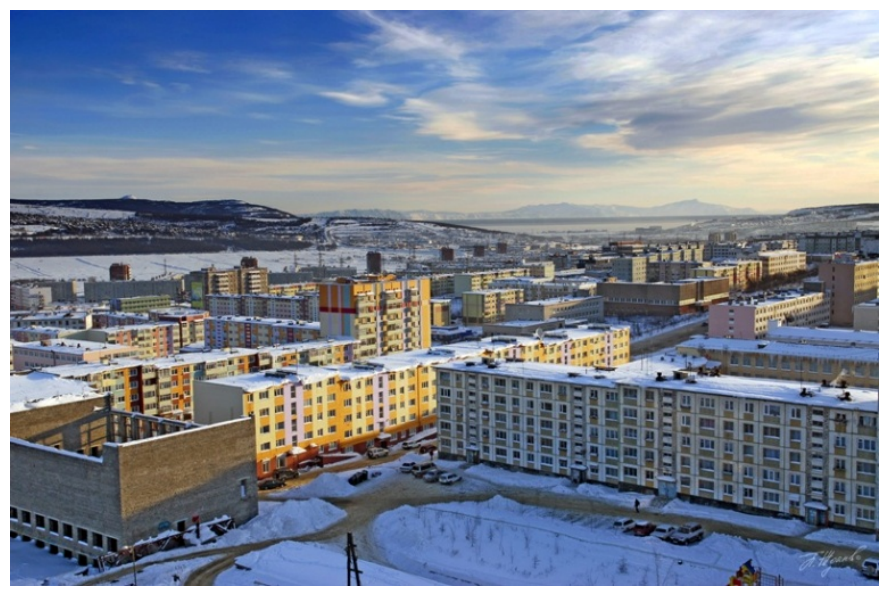

Photo 1. Magadan. 2014. CAndrei Osipov

The Russian Far North is an area with a low-density population, high risk agriculture, geographically distant from the centre and with high cost of infrastructure building including, crucially, transportation. The discovery of industrial quantities of gold, silver and other metals in the beginning of the 1920 s made development of this region economically profitable, as considerable state investment received a big return when the country needed gold revenues to finance major state projects, such as industrialisation and post-World War II rebuilding. Rich mineral resources determined the particular way, in which the region had developed, where major infrastructures, such as geological exploration, the energy sector and transportation, were built around the extractive industry. Such development projects needed a labour supply. The task was addressed in a planned manner. Starting in the late 1920 s, mining and construction work was done by a combination of free and forced labour, brought from all over the Soviet Union, and from the mid-1950s onwards, by free labour, i.e., volunteers working on contracts. This work of a free labour force was compensated with increased wages, early retirement, and paid vacations taken outside the region. As a result, the population of the region increased rapidly, from approximately 5 thousand people at the turn of the century (most of whom were local Native people) to 113,4 thousand in 1938 (Polyanskaya and Raizman 2009) and to 391,6 thousand at the demographic peak in 1989 (Statisticheskiy Ezhegodnik 2008). The massive influx of people required the building of socio-economic infrastructures, which previously assumed a 
secondary importance to the industrial developments. It was only in the postWar years when, prompted by new waves of recruited labour, socio-cultural development was slowly catching up. The numbers of living accommodation, kindergartens, schools, hospitals, theatres, and museums were expanding; the sex ratio that was originally skewed towards the prevalence of males had evened out, and the territory started resembling many other territories in the former Soviet Union, save the distance and northern climate.

Yet after peaking in 1989, the region began losing its population. Coinciding with the onset of Gorbachev's perestroika, people started leaving this area, at first in a trickle, and then as an avalanche, for the regional population decreased from $391,6(1989)$ to 165,8 (2008) to 157,0 (2010) and to 144,0 in 2017. The local and federal governments, and international organisations such as the World Bank, assisted them in relocating either to other communities within the region or outside the region. The rate of outmigration has been quite astonishing even for the Far Eastern Federal Okrug, reflecting the changing economic environment, but also revealing very interesting social dynamics, which will be the focus of this paper.

In this article we wish to examine some outcomes of the two interrelated state projects: the regional development and induced migration. We are particularly interested in the consequences, intended and unintended, of these projects, and in the relationship between various levels of the state apparatus in maintaining the post-Soviet North.

Theoretically, we are placing our data within three conceptual frameworks: anthropology of the state, anthropology of globalisation and Actor Network Theory (ANT). In Anthropology of the State we focus on the conceptualisation of the state other than a singular entity. The monolithic character of the Soviet state was an example of the perception of the state as singular, dominant, bounded and representative, although even in Soviet times it was multiple in a different way (I shall come back to this in Part 2). This is of course not uniquely Soviet: as Migdal and Schlichte maintain, "the modern state as a singular actor... is one of the most commonly held images in today's world across diverse areas and cultures" (2005: 14). Yet "the state" as a category could be differentiated into 'state as an image' and 'state as a practice' (Althusser 1989, Abrams 1988, Migdal and Schlichte 2005, Sharma and Gupta 2006). According to Migdal and Schlichte, these two interrelated aspects of the state, necessarily lack unity and coherence, and could reinforce each other, or run in opposite directions. Furthermore, "both the image and practices of the state involve power, which can flow from state actors to non-state actors and in the opposite direction"; and the process of exercising power involves struggle among multiple actors, both state and non-state and occurring at multiple sites (Ibid: 15). 
During the post-Soviet period the state had been transformed from a seemingly ultimate single actor to a multiple actor. The two state projects under scrutiny give us an opportunity to observe the separation of the postSoviet state and power struggle along two axes: 1 . Within the state, between three levels of the state, federal, regional and local (i.e., raion or municipal). Despite some agreement on all three levels as to the value of the Russian Far North as a strategic outpost of the Russian Federation and a mineral resource base, the political and economic relations between these levels are marked by tensions necessitating negotiations. 2 . Between the state and people: we shall see how state policies regarding relocation were met by people on the ground. In people's narratives the term 'state' floats across all three levels, the federal, regional and municipal, being used in diverse contexts, as one of these or all of them. The state became a multiple actor not only within economic and political frameworks (as practice) but in people's minds as well (as image).

The northern development project of the Russian Northeast was, and still is, a state bounded project, a planned social and material space and order that James Scott called high modernist (1998). Clear aims of northern development and targeted use of certain tools, i.e., designing programmes to increase, or more recently, to reduce the population in the Russian Far North by relocating a "surplus" population to reach an "adequate" number, point at the social engineering character of these initiatives, then and now. Yet neither the Russian government nor the World Bank, both assisting northern residents to move out of the North, fully achieved their goal: people who were meant to relocate resisted such plans and stayed in the region, or, having taken advantage of assistance, returned to the region.

John Law's concept of social ordering is particularly helpful to understand why this is so (Law 1994, 2001, 2008). According to Law, Actor Network Theory focuses (among other things) on ordering as an activity. For him, social order is not an order but a process of social ordering, where "social" is a materially heterogeneous set of arrangements that include, besides people, documents, codes, architectures, physical devices, infrastructures, etc. An organisation is a materially heterogeneous process of arranging and ordering, and that process, Law maintains, may be understood as a set of implicit multiple strategies or as a mode of ordering. Organising is, according to Law, about complex relationships between different modes of ordering, and organisations work because they are non-coherent. An attempt at a single version of reality, a "pure form" characteristic of social engineering projects do not survive for long because the real world is messy and resists purity (Law 2001). As far as state-building is concerned, social ordering - the set of arrangements that convinced people that there is such an entity as the state - has to be kept in place, to be kept going, or improved, but always worked on and propped up. 
Although we are looking at internal migration, globalisation studies lend useful tools in analysing migration-related issues of hybrid identity and multiple place-attachments described for transnational migrants as in Appadurai's concept of translocality, or geographical imagination of migrant workers who have their roots in two countries, modifying vision and habits of their home country and of their new home (2003). The concept may not be entirely applicable to a place like the Kolyma: although it brought together people from many other localities, with time many of them, instead of re-creating their former local identities in the Kolyma (or perhaps along with re-creating), acquire the 'northern' identity, which they later take back to the places outside the North. Yet even they did not leave their previous "homelands" behind, much like transnational migrants, maintaining social relations at a distance: "Migrants today often form what might be called diasporic attachments; this refers to a dual affinity or doubled connection that mobile subjects have to localities, to their involvement in webs of cultural, political, and economic ties that encompass multiple national terrains" (Inda and Rosaldo 2008: 21). Within this paradigm Ulrich Beck developed his concept of place polygamy, which is a practical attachment to two homelands. Beck describes an elderly woman who lives in Germany but travels to Kenya. Both places, he maintains, she could call "home" (Beck 2000:72). This paper will illustrate limitations of this concept.

\section{The (de-)populating of the North as a state project(s)}

Planned lifecourse: Permanency and fluidity in the region. The population of the Magadan Region has always been mobile: during the Dal'stroi era (1931-1953 ${ }^{4}$ ) and after 1953, when forced labour workers were freed, they left the region in tens of thousands, while the state had to devise ways to bring fresh labour forces in. This included material incentives and the ideological construct of the North as a heroic frontier, in which individual lives were to be situated. Recruited free workers and specialists arrived and left after their contracts had come to an end. Yet many people stayed, extending their contracts; new recruits were coming; and the first and second generations of Magadan Region residents had been born. Moving to the region was not easy. The state regulated population inflow according to the local economic needs, and before 1991 this being a border zone, access to this region was allowed only by special permission.

Along with the planned fluidity of the human labour force, there was something that was seen as permanent: that was the state as a seemingly single actor with its centralised economy and decision-making, and the geographical place itself. The presence of the state had at least two aspects to it. One was the evident and tangible materiality of the state northern development project. Here we refer to the non-human element in the ANT, 
the results of the construction of the roads, mines, communities with their infrastructures, of the ports and fishing fleet, hydroelectric stations, factories and many a sovkhoz, and other physical elements that made living in the North possible. But infrastructures are not just concretized aspirations, values, or meanings, maintains Bennett, they are fragile, unruly, and unpredictable assemblages of people and things (2010). In these assemblages, infrastructures are implicated in the constitution of collective social order emerging from humans' entanglement with the material world, a process of emplacement by people working together and producing these material effects.

The second aspect is the continuation of the first one but in the area of human perception. Marked by the purity of single vision, the northern development project was based on the idea of the linear progression into the future, of growth and expansion: given the riches of this land, the vision for the Northeast was to explore and find more mineral resources, to build more elements of infrastructure, and to attract more people. The Head of Municipal Administration of Kholodniy, now a small community of 1215 persons near Susuman, told us in her interview in 2009: 'In the 1980s we had about 4 thousand people and we were planning to increase this number to 7 thousand by 2010 '. Indeed, the regional population was steadily growing until 1989 although mostly in urban areas and in the minds of many people the state presence and expansion looked very solid.

Not only the regional development but individual life courses were also modelled around the idea of linear progression: to finish schooling, to start a family, to find a job, and, importantly, to grow in professionalism. The latter not only required time but there was an understanding that at certain times in his/her life course one has to occupy a place appropriate to his or her age and professional development. The idea was that one does not change careers in the middle of professional development. Permanency on the job was encouraged, while propiska (housing registration with police) requirements made it difficult to move places. Finally, retirement was envisioned as sedentary and rooted, centered on tending one's vegetable plot on a dacha and looking after grandchildren, usually not doing wage work, and not travelling. Northern living modified this model to produce a distinctly northern version, namely, the North was envisioned as being for younger people who would dedicate ('give') their working years to the North, and upon retirement move back to the materik. The North, it was thought, was for doing rather than just being, so people were expected to retire elsewhere. Hence if in the materik many people settled in their younger years to acquire social, professional and family networks, flats and dachas, and retired in the same environment, the northerners, upon retirement, were expected to move away from their familiar northern environment. As we shall see, this instituted model of northern living was not without its consequences for both 
the post-Soviet state and individuals. Hence the life cycle of individuals was, and still is, seen as circular and bounded: with the North being only a stage in one's life and upon retirement, that circle had to come back to itself in the materik. On the contrary, the life course of the region was imagined as open-ended and permanent. Labour force was fluid while the state was there to stay $^{5}$. Until in the 1990s it imploded; this collapse was perceived as unreal and unthinkable.

State withdrawal? Hence from the 1990s this seemingly permanent feature of the state had rapidly crumbled, as our expedition of five people on the Kolyma Road, or Kolymskaya trassa as it is called locally, easily reveals. Kolymskaya trassa is a $2000 \mathrm{~km}$ road to Yakutsk connecting Magadan city and its ports with a multitude of regional communities. The paved road goes only $70 \mathrm{~km}$ as far as a small town Palatka, and then it becomes a dirt road. By the 2000s, communities along the trassa laid in various states of disintegration: here comes Atka, built as a road construction auxiliary hub in the 1930s while the trassa was being built by Dal'stroi, and then becoming a petrol distribution hub, with 2648 people living there in 1989. Only a handful of people live there today. Huge metal gasoline storage tanks are now caved in. Small houses made of wood and many three-and four-story cement buildings are abandoned, doors broken, hanging open, and wooden floors taken to heat the remaining buildings. Abandoned administrative buildings with walls of peeling paint look at us through their broken windows. From many cafeterias that used to serve local people and fleets of long-distance truck drivers, only one small kitchen operation is open, now private. We drive further. 'Here is Strelka', says our driver, pointing to the right at the empty field. Elena K.-R., one of the authors strains her eyes, but sees nothing. He stops the mini-van we are travelling in and gets out, walks a few metres and stands on grass. Here, he stomps his feet, and we see barely visible pieces of wood and broken bricks and finally make out traces of a building foundation. We are amazed at how quickly the slow-growing northern nature claims back the land once wrestled out from it by a concerted human effort. Strelka is razed to the ground with grass growing over it. We are going by Myakit built in the 1930s around a gold mine and a labour camp for over 6,000 people, one of many transportation maintenance and repair communities providing road service and supporting the transportation network along the trassa, which enabled necessary equipment and supplies to be distributed where they were vital. A few hastily built tiny wooden shacks cluster together where in 1989 a community of nearly 700 people worked in road maintenance, a cafeteria, a medical facility, and a hotel. Spornoye (2567 persons in 1989) looks like Kadykchan (5794 people in 1989) - both have buildings intact with absolutely no residents (Photo 2). 


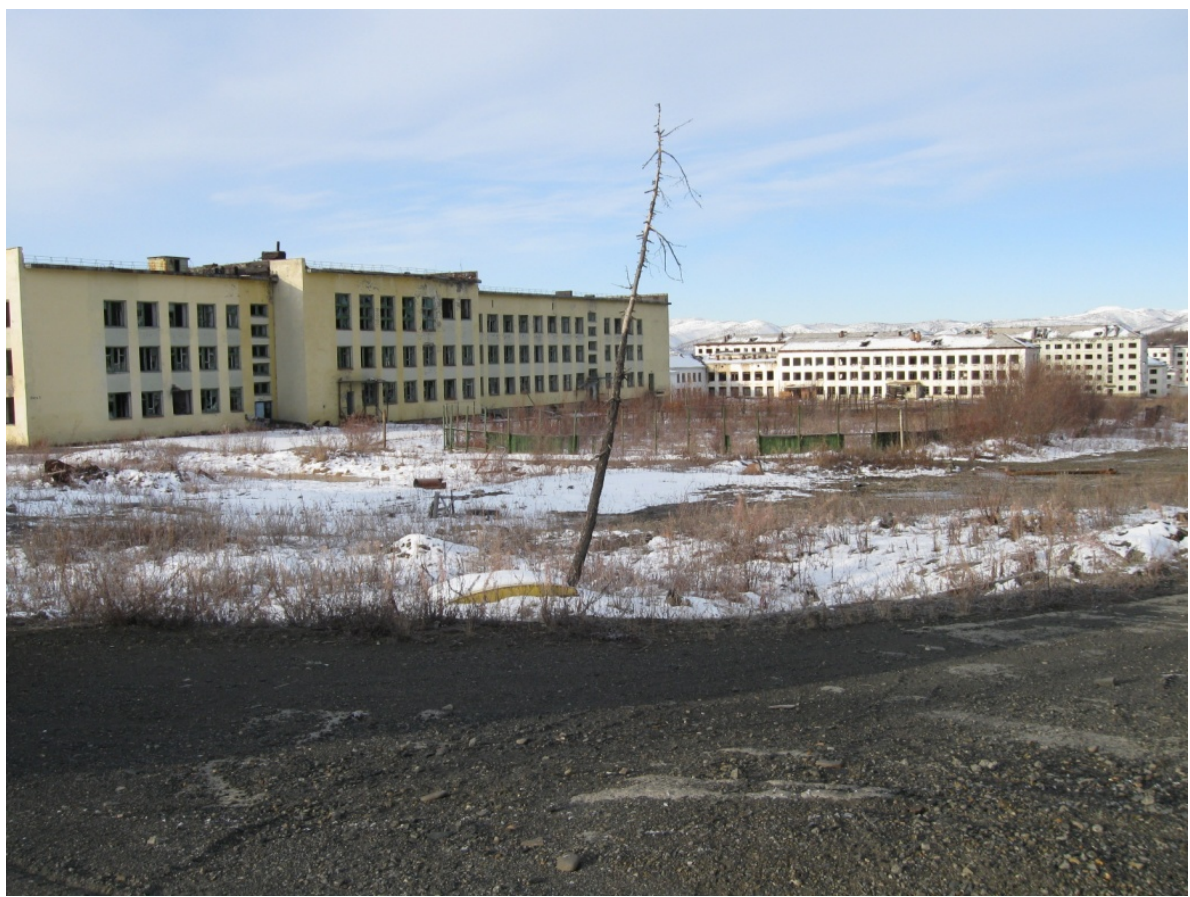

Photo 2. Abandoned town Kadykchan. September 2010. (C) Andrei Osipov

They are completely abandoned together with state enterprises around which such communities were built ${ }^{6}$. The population of Sinegor'ye, a town serving the still working Kolyma Hydroelectric station, that used to have 11,645 people in 1989 , now barely counts 3,000. Anymore, it surprises me to see towns showing signs of life, like in Yagonoye, the third largest town after Magadan and Susuman. There the population has been reduced by twothirds, local industries are literally in ruins, like in many other communities. Factories, sovkhozy, greenhouses, airports are abandoned and, owing to the severe northern climate, disintegrating rapidly, unless reused. Those people who stayed can salvage bits and pieces but otherwise they live amidst ruins, watching the process of decay. The state has left. Or has it?

These are the consequences of the political and economic restructuring of the northern territories, which in 1991 went from centralised state controlled, to supposedly market-oriented. The main idea behind of what looks like the withdrawal of the state was the notion that the North was over-populated and unsustainable (Hill and Gaddy 2003). Some local social scientists shared this view but with a caveat: the North was over-populated with regards to the industrial base that was created within the socialist planned and centralised economy (Kokorev, Pilyasov, Yadryshnikov 1994). Inability to sustain this industrial base produced what was called a 'surplus population'. 
The economic restructuring process started from the short, but seminal 1992 visit of the then First Deputy Chairman of the Russian Federation Egor Gaidar to the Magadan Region who literally pulled the plug. He spoke from the point of view of the still undifferentiated state and government of that time, which in the words of a federal government official, believed that 'we as a country do not need anything beyond the Urals'. A member of the Committee for the North of the Council of Federation added, "That government thought that we need to forget about the North, to pump out resources but not investing in the North, not developing it". When the stateinduced population movement is directly tied up to a mono-industry and economic profitability, the fall of the latter spells disaster to the former ${ }^{7}$. With the institution of (a new ${ }^{8}$ wave of) federalism in the contemporary Russian Federation in 1993 and the separation of the state into three levels, the Federal Centre, Regional and Local administrations, the federal authorities continued construing the North as a demographic and economic burden. Federal investments were decreased, state enterprises closed, people lost their jobs, resulting in waves of outmigration that reduced the regional population by nearly $60 \%$. The policy of attracting labour with material incentives was labelled as 'distorted', and there was a call to remove northern privileges, aimed at placing "the North on a more equal footing with other Russian regions, and reduce its attractiveness for in-migration" (PAD WB 2001: 4). A number of relocation programmes funded by the Russian government and by the World Bank helped people to realise their wish to move away from the North (Nuykina 2011). These programmes streamlined and intensified the two processes that were already in place even before the 1990s, which was to assist in outmigration (labour fluidity typical for this region) and to help with obtaining accommodation in the materik (some schemes have already been working in the 1960s-1980s) ${ }^{9}$.

As a result of this line of thinking on the federal level, the state seemed to have gone away as I illustrated above, leaving a void. This void was filled by private initiative. Hence many formerly state stores are now divided into cubicles rented by private retail shops. Food supplies and retail business is entirely private. Gold extraction is done by a multitude of private businesses, from tiny and often illegal individual operations to multi-national corporations. Many companies in the energy sector are share-holder's organisations and thus are privatised. Healthcare, education, and administration is what is left of the state structures.

Separation of the state. Yet not everything is the way it appears. A closer analysis reveals that not only the state did not go away, but in many ways, currently as well as in the future, the fate of the North seems to be firmly connected to state investments. Let us explain. The separation of the state produced distinct actors, federal, regional and local governments, the Committees for the North in Federation Council and the State Duma, each 
with its own understanding of what the North is for, and what to do about it. They converge in some views but not in others.

On the one hand, the model of northern living that views the population of the Northeast as sedentary but not permanent is not a thing of the past and persists on the state levels. A member of the Committee for the North in Federation Council still thinks that,

The North is not for pensioners. Currently the number of old-age people in the North and in Central Russia are about the same, but in the North pensioners cost the state 3-4 times more than a working age person. We are also facing the shortage of working-age people in the North. The optimal number of people should be enough to fulfil the labour needs of a given region. Of course pensioners have the right to live wherever they wish but from the medical point of view, they are better off on the materik as it has been proved that the North is harmful for one's health if one lives there for more than 5 years.

A Magadan politician agrees:

Permanent population is impossible in the North due to the geographic economy of the region. Arkhangel'sk is an example of a traditional northern place of residence but it is closer to central Russia. It is different here: people live where there are jobs, jobs are where money is, and the money follows the state policy. In this region there is no work area that would require long-term need for permanent labour resources.

Another long-term Magadan resident working in politics and education considers: "A person should give the North the best years of his working life and then leave. This is why it is important to keep a personal network in the materik as well".

On the other hand, the 1990s ideas of the Russian government, i.e., that the whole Northeast could be manned by fly-in and fly-out shift labour, have faded into the past, although seasonal gold mining-related migration exists de-facto practiced by private companies. Likewise, Gaidar's (and World Bank's) idea, that a free market will sort out everything and there is no need to support the North, some consider non-viable: "The hopes that a free market would regulate all aspects of the national economy using only tools of financial stabilisation on the macro-level is utopian, especially in the environment of globalisation of the world economy and the need to implement the "catching up" scenario of development." (Zausaev et al 2010: 40). The oft-repeated idea of over-population is also being contested. Thus, as early as in 1994 an economist Kolomijtsev already demonstrated that Kamchatka was not over-populated but on the contrary, under-populated and the policy of relocating people would lead to losing working age individuals, which was contrary to the intentions of the government (1994: 51-52). A member of the State Duma Committee for the North now shares this view, stating in an interview in 2009: "Two-thirds of the Russian Federation are 
northern territories with low population densities, only 10,7 million people. It is under-populated." A member of the North Committee of the Federation Council maintains that the economy is growing and so are the needs, while many people have left the region, especially working age individuals: "There is shortage of labour in the Magadan Region as we speak; we need to attract some 20,000 foreign workers who need to be hired to fill the gap." Even the issue of supposed economic un-viability of the North is being contested. If political and economic dependency of the regions on the centre will be reduced with local governments having more freedom in decision-making, and more funds remaining in the regions instead of being sent to Moscow, the North will be economically viable.

What everyone agrees upon is that the North is needed. What to do with it is another question.

The (Soviet) clarity of vision for the North that was translated into coherent state policies is no more. Interviewing members of federal and regional administrations I asked two questions: Is there a state policy regarding the North? Does the Russian Federation need the North? The answers were quite uniform: the country needs the North for its resources and as a sovereign border territory that must be populated and protected, but the state policy is either absent or at best 'diffused'. This 'diffused' policy is what we shall dwell on next.

Federal government: diffused policy but a firm grip. The Soviet state policy regarding the Northeast was developing over time via negotiations between local Soviet and Party structures and the central government, as explained in 2009 by a sociologist, native to Magadan:

The interests of the state and of people coincided then. Not surprising given the North's riches but sparsely populated area. The state policy was to increase prizhivaemost' (sedentarisation), and at that time the funds were available for the Far East and Siberia. We were putting forth proposals regarding northern benefits and increased salaries. We knew what to do and what for. But now... now the policy is completely diffused. Until 1993 there was the State North Committee and we were striving for it to become a Ministry. We did not succeed and eventually it disappeared altogether. Why? Who knows? Probably has to do with the overall situation in the country, the absence of perspectives. Everyone understands why we need the North but perhaps it is difficult to get away from the idea of having oil and the ease with which the country's purse could be filled with oil money. The situation is so complex that they think maybe tomorrow, maybe somebody else [would deal with the North]. There is no thinking about the future for the country.

A member of the Committee for the North at Federal Council recalls:

In 1999 I was in Canada, visiting the Minister of Foreign Affairs, who told me that they [in Canada] were studying our way of exploring and developing the North and even adopted some of our strategies, including 
regional development. When that northern development policy was demolished, it became very difficult for us to work. We were writing to different Federal bodies to help us. It is becoming clear that the country's economy will be developing on the account of raw resources... and this is first and foremost, the North! But those people who are deciding on many issues vital to the North live within the Sadovoye Kol'so in Moscow, they know very little about the North. The northern regions are very different in their natural environment, energy and transportation networks. How to convince them that northern territories require special treatment, that there must be a differential policy, territorial tax breaks? Say we visited a hospital in Petropavlovsk-Kamchatskiy where walls were covered with mould because the money that was sent to them was spent on buying fuel? That if you take away $80 \%$ of a person's income in Voronezh and in Magadan, it will be two different things? Many northern benefits were discontinued ${ }^{10}$ and we are fighting against it. But in the best case scenario we shall barely regain what we had in Soviet times.

The North Committees in the State Duma and in the Federation Council represent the North's interests in the Federal Government. They consider that the lack of coherent policy and adequate funding for northern development is coupled with the (still) colonial attitude towards it, namely, that the North is needed only as a resource base and the policy seems to be to not do much, gloss it over with silence and 'pump out as much as you can without giving anything back' (interview with a member of the North Committee in the Federal Council). In an attempt to explain this paradox, that the North is rich but not much has been done in post-Soviet time to develop it, many state agents agree on a point that the 'diffused' policy has to do with the overall situation in the country, where the country is undergoing drastic restructuring addressing simultaneously many problems, changing the forms of property ownership and where other pressing needs (i.e., Northern Caucasus) require more immediate attention and funding.

So, to repeat the first statement, the (federal) arm of the state is lacking the single vision for the North, although the reasons for not letting it go are clear and oft-repeated by government officials and local people alike: the country's resource-based economy requires resources and 'if we don't live there/use the resources, somebody else will (meaning the USA or China)'. This, it appears, prompts the state to keep the North at a heel even if undecided yet how to go about developing it, and this indecision constitutes the 'diffused' character of the policy.

Yet even with a diffused policy the participation of the federal government in maintaining the North is surprisingly considerable. Thus, as early as 1996 a Federal Programme "Economic and Social Development of the Far East and Zabaikal'ye ${ }^{11}$ until 2013" had been instituted. What interests us in this document is the proportional participation in the key projects in the 
Magadan Region at federal, regional and municipal levels of the state. The amount of money given to projects in the region between 2008 and 2013 amounted to $33801,7 \mathrm{mln}$ Roubles, from which 31370, $9 \mathrm{mln}$ are from federal government, $1435 \mathrm{mln}$ (regional), 101,9 mln (municipal) and $893,9 \mathrm{mln}$ (other sources). The key projects in the energy sectors are implemented by share-holder's companies with $52,68 \%$ of shares belonging to the Federal government, making it state-owned. The rest of the projects have federal, regional or municipal ownership. The Kolyma trassa is a federal road. Federal money had been invested into the reconstruction of the Magadan airport, building of the new department of the regional hospital (co-financed with Magadan municipality) and the building of the eagerly awaited Ust'Srednekan Hydroelectric station that will supply electricity to a mine with a substantial gold deposit ${ }^{12}$. Many private initiatives with tangible results took place because of federal investments. National programmes such as 'Education', 'Healthcare' and 'Agriculture', together with local support allowed development of local farms that produce fresh dairy instead of longlife milk from Moscow, and setting up computer classes in far-away communities such as Susuman (Photo 2). Moreover, the Federal government controls the extractive industries by the way of licensing and regulations (i.e., the gold-mining by individuals is still unlawful); and harvesting of bioresources by setting quotas for Native people and fish-processing factories. The Magadan Regional budget is heavily subsidised ${ }^{13}$ : in $2009,67,4 \%$ of the Magadan Regional budget was funded from the Federal budget (dotatsii, or non-specific funds). The Special Economic Zone, offers a profits tax exemption on investments in the development of production or the social infrastructure up until 2014 and a property tax exemption for the first 5 years, allows boosting the local economy and attracting foreign investment.

The supposed absence of the state, then, despite many gaping holes, is an erroneous conclusion. Moreover, the future of the region is firmly connected with federal investments into mega-projects, such as building a railroad, a branch off BAM, via Yakutsk to Chukotka, branching off in Magadan. The project was supposed to start in 2016 and be completed in 2030. This rail road would provide vital connections to the mainland, which will allow developing the resource base more fully. The "diffused" policy towards the North hangs on the promise of a future Klondike. The future exploration and extraction of gold, silver, coal and oil depends on the development of the energy sector and transportation network, because, in the words of one local administrator,

It is not enough just to mine gold - what do you do with it after that? There must be logistics in place to transport it and process it. It is down to federal investments as big business will not be able to do it on its own. The North is of strategic importance but to invest in it is very risky for businesses because all projects will have to deal with increasing costs due to the absence of transportation and energy infrastructures. 
The absence of these very infrastructures is what impedes the economic development. According to Aleksandr Basanskiy, a member of the Regional Duma, of the pro-Putin's United Russia political party and the owner of one of the largest gold-mining companies, "Magadan Region is very attractive as far as investments are concerned but due to the poorly developed infrastructures, it is distant perspectives." The hopes of attracting foreign investments and a closer affiliation with the Asiatic-Pacific Region constitute, perhaps imaginary, stimuli for local administrations' initiatives aimed at economic development of the region ${ }^{14}$.

Hence the North is viewed by all levels of the government as important. But on the national level, management of the Russian Northeast seems to be guided by statist thinking: it is a territory that the country needs for its resources and lately, for military purposes, where distribution of population needs optimisation, and the population should be relocated/resettled according to the new economic realities, and fresh labour supplies should be brought in where needed, hence the 2016 'Far Eastern Hectare', a programme of giving away land to any interested citizen of the Russian Federation (https://xn--80aaggvgieoeoa2bo7l.xn--p1ai/). As far as the pattern of state presence and absence is concerned, the state controls key positions in healthcare, education, energy, transport, financial and resource extraction areas, leaving retail sales to the domain of private enterprise.

Lately, however, the increased importance of the Arctic and sub-Arctic regions ${ }^{15}$, along with continuing negotiations between the federal and local governments produced tangible results.

The 2009 programme, "Strategic development of the Far East until $2025^{\prime \prime 16}$ had been hailed as a sign of the Federal Government 'turning its face to the needs of the North'. In this document the main problems of the Far Eastern region were at last clearly spelled out: the importance of the natural resources, the absence of the clear state policies towards the Far East (including northern territories) and the danger of these regions being turned into a resource base for Asiatic-Pacific countries, of the rapid and continuing de-population and the need to retain people in this region by creating a welldeveloped economy and comfortable living conditions for them and to optimise' the system of population distribution. The documents outline factors that restrain economic development, such as economic and infrastructural isolation from other parts of the RF, poorly developed transportation networks, low population density with patchily populated areas, high risk agriculture and seasonal character of supply provisions. Also mentioned are the high costs and heavy reliance on transportation, harsh climate, undeveloped and costly energy and transportation infrastructures, which are a direct or indirect obstacle to any activity and operation in the Far East, and the low competitiveness of local industries. This is a comprehensive strategy based on "the state, business and society working 
together as partners to realise key investment projects". Although the funding for this programme was cut by $80 \%$ almost right away, it was a step forward in recognising the need to take the Far Eastern Region seriously. The recent 2018 military exercise in the Arctic clearly mark a renewed interest in the northern territories, which have been kept on the back burner and never let go.

To be continued. In the next issue we shall demonstrate how social engineering projects are bound to partially fail. Despite the federal government's diffused policy with its hands-off approach towards the Northern territories and calculated economic rationality behind such a northern development project, local administration and local people with their collective agency put forth tangible resistance without being organised or making a collective effort. We shall look at the local survival strategies and rationale behind individual decisions that support the viability of northern communities while circumventing the state's imposition of a single (economic) order.

\section{Footnotes}

${ }^{1}$ This paper is based on ten months of fieldwork during 2007-2009 in the Kolyma Region. All names have been changed.

${ }^{2}$ Over 30 nationalities in total, such as Even $(1,6 \%)$, Tatars $(0,9 \%)$, Belorussians $(0,7 \%)$, Chukchi (0,28\%), Eskimo (0,02\%) and others (All-Russian Census 2010).

${ }^{3}$ There is no rail road connecting it to other places; ships are for cargo only and the dirt road connecting Magadan to Yakutsk is mostly for local commuting and cargo.

${ }^{4}$ When the Main Headquarters of Dal'stroi was transferred from Ministry of Internal Affairs USSR to Ministry of Metallurgy USSR, while the Dal'stroi's labor camps - to GULag of the Ministry of Justice USSR.

${ }^{5}$ Which was probably a reflection of the general perception of the state as an eternal state as Yurchak had convincingly demonstrated: the feeling of Soviet life in general was as having a fixed and immutable nature, although the feeling of the state as a fixed single entity did not preclude the existence of internal shifts and mutations, and "the more the system seemed immutable, the more it was different from what it claimed it was" (2006: 295).

${ }^{6}$ The enterprise that constitutes the economic base of a community, or gradoobrazuyushchee predpriyatiye.

${ }^{7}$ Not only in the North. The problem of mono-industrial towns, such as Pikalevo (Leningrad Region) had been discussed widely in the media and social sciences (i.e., Zausaev, Dubinina, Zaitsev 2010).

${ }^{8}$ The first wave in the XX century took place in 1917-1924 that ended with institution of quasi-federalism (Fedosov 2001: 17).

${ }^{9}$ Even in the Soviet times the state assisted people in obtaining accommodation. People moving to work in the North had the right to reserve their flats in the materik, most received state flats in the Kolyma, which they were able to exchange for the flats in the materik, still others built co-operative flats there through institutions where they worked and through the city administration.

${ }^{10}$ Some of them were re-instituted.

${ }^{11}$ Territories east of the Baikal Lake.

${ }^{12}$ The building of this station was planned in 1978 and started in 1990, due to be completed in 2013. The mine is "Matrosova Mine" (Natalkinskoye gold deposit estimated at 600-800 tons), 
with the Noril'skiy Nikel', a Russian private company being the main investor into the mining operation.

${ }^{13}$ Subjects of the Russian Federation (including northern territories) are divided into two categories: those with surplus budgets and those with deficit budgets. Magadan Region belongs to the latter category.

${ }^{14}$ As in the recent proposal by the Magadan Regional Administration to develop a project of "Complex processing of the brown coal in the Magadan region", where the administration is looking for an investor that would contribute some 18,8 mln Roubles into the project.

${ }^{15}$ Alternatively, according to some, the increased visibility of the North was a part of the political agenda related to "development, support and realisation of the idea of modernisation during the election to the State Duma" (Interview with a Far Eastern political scientist Petr Khanas to newspaper Vladivostok, N2862, 11 January 2011, URL: http://vladnews.ru/2862/ Aktualno/Kak bi_vibori)

16 This "Strategy" was developed in accordance with another document, the "Concept of long-term socio-economic development of the Russian Federation until 2020" (17 November 2008, № 1662-r.) URL: http://dfo.gov.ru/index.php?id=80

\section{References}

Abrams P. Notes on the Difficulty of Studying the State, Journal of Historical Sociology, 1988, no. 1(1), pp. 58-89.

Althusser L. Ideology and ideological state apparatuses. In: Lenin and Philosophy and other Essays. London: New Left Books, 1989.

Appadurai A. Sovereignty without territoriality: notes for a postnational geography. In: Low, S. and Lawrence-Zuniga, D. The Anthropology of Space and Place. Blackwell Publishing, 2003, pp. 337-351.

Beck U. What is Globalisation? Polity Press and Blackwell Publishing, 2000.

Bennett J. Vibrant Matter: A Political Ecology of Things. Durham, N.C.: Duke University Press, 2010. Cited in Fennel, C. 2015. 'Emplacement.' Theorizing the Contemporary, Cultural Anthropology website, September 24. URL: https://culanth.org/fieldsites/716emplacement.

Fedosov P. Federalism in Russia. In: Khakimov R. (ed.) Federalism v Rossii [Federalism in Russia]. Kazan': Institute of History, Tatarstan Academy of Science, Kazan' Institute of Federalism, 2001.

Hill, F. and Gaddy, C. The Siberian Curse: How Communist Planners Left Russia Out in the Cold. The Brookings Institution, Washington D.C., 2003.

Inda, J. and R. Rosaldo. Tracking Global Flows. In: Inda, J. and R. Rosaldo, The Anthropology of Globalisation of globalization: a Reader. Blackwell Publishing, 2008.

Kokorev E., Pilyasov, A. and G. Yadryshnikov. Severnaya Periferia: Poiski Formy Vyzhivaniya [Northern periphery: searching for forms of survival]. Kolyma, 1994, no. 1, pp. 2-6.

Kolomijtsev F. Population Stability as a Factor of Sustainable Socio-Economic Development of the Kamchatka Region, 1994. URL: http://ecsocman.hse.ru/data/765/ 846/1217/011Kolomijtsev.pdf

Law J. Organizing Modernity: Social Ordering and Social Theory. Oxford: Blackwell Publishing, 1994.

Law J. 'Ordering and Obduracy', published by the Centre for Science Studies, Lancaster University, Lancaster LA1 4YN, UK, 2001. URL: http://www.comp.lancs.ac.uk/sociology/ papers/Law-Ordering-and-Obduracy.pdf

Law J. Actor-Network Theory and Material Semiotics. In: Turner, Bryan S. ed. The New Blackwell Companion to Social Theory, 3rd Edition. Oxford: Blackwell Publishing, 2008.

Migdal J. and K. Schlichte. Rethinking the State. In: Schlichte, K. (ed). The Dynamics of States: the Formation and Crises of State Domination. Ashgate Publishing, 2005. 
Nuykina E. Resettlement from the Russian North: An Analysis of State-induced Relocation Policy. Rovaniemi, Finland: Arctic Centre, University of Lapland, 2011.

PAD. 2001. Project Appraisal Documentation: A Proposed Loan in the Amount of US\$80 Million Equivalent to the Russian Federation for a Northern Restructuring Project. Report No: $20090 \mathrm{Ru}$. May 4, 2001. Human Development Sector Unit. Russia Country Department Europe and Central Asia Region. Document of the World Bank.

Polyanskaya, E. and D. Raizman. Stanovleniye i razvitiye organov statistiki Magadanskoy oblasti [The setting up and development of statistics bureau in the Magadan region]. Unpublished manuscript in possession of the author. 2009.

Rosstat. 2018. Municipal population of the Russian Federation on January 1, 2018. Federal Agency for State Statistics. Moscow 2018. URL: http:/www.gks.ru/wps/wcm/ connect/rosstat_main/rosstat/ru/statistics/publications/catalog/afc8ea004d56a39ab251f2bafc3 a6fce (Tabl-03-18).

Scott J. Seeing Like a State: How Certain Schemes to Improve the Human Condition Have Failed. Yale University Press, 1998.

Sharma A., Gupta, A. (eds). The Anthropology of the State: a Reader. Oxford: Blackwell Publishing, 2006.

Statisticheskiy Ezhegodnik [Annual Statistical Data]. 2008. Magadan Region. The Territorial Branch of the Federal Statistic Service. MagadanStat, Magadan.

Zausaev V., Dubinina, E. and K. Zaitsev. Politika Zanyatosti v Monogorodakh. [Employment policy in mono-industrial towns]. Moscow, Moscow social sciences fund. Far Eastern science research institute of labour market. Series: Scientific reports: independent economic analysis. N213. Moscow, 2010.

Статья поступила в редакцию 1 октября 2018 г. 